\title{
Food, farm and rural policies after Brexit? Some knowns, and known unknowns
}

Article

Accepted Version

Swinbank, A. (2018) Food, farm and rural policies after Brexit? Some knowns, and known unknowns. Eurochoices, 17 (2). pp. 4-11. ISSN 1478-0917 doi: https://doi.org/10.1111/1746692X.12197 Available at https://centaur.reading.ac.uk/78782/

It is advisable to refer to the publisher's version if you intend to cite from the work. See Guidance on citing.

To link to this article DOI: http://dx.doi.org/10.1111/1746-692X.12197

Publisher: Wiley-Blackwell

All outputs in CentAUR are protected by Intellectual Property Rights law, including copyright law. Copyright and IPR is retained by the creators or other copyright holders. Terms and conditions for use of this material are defined in the End User Agreement.

\section{www.reading.ac.uk/centaur}

\section{CentAUR}

Central Archive at the University of Reading

Reading's research outputs online 


\title{
Food, Farm and Rural Policies after Brexit? Some Knowns, and Known
}

\section{Unknowns}

\author{
Alan Swinbank
}

Following the referendum on the UK's membership of the EU in July 2016 Theresa May replaced David Cameron as Prime Minister. On 29 March 2017 Article 50 of the Treaty on European Union was triggered, commencing the withdrawal process, and in June 2017 a General Election was held in which Mrs May clung to power. In a number of speeches the Prime Minister set out her vision for Brexit, and members of her Cabinet - and others - enunciated theirs. In December 2017, after lengthy discussions, a Joint Report covering citizens' rights, the Irish border, and a financial settlement was produced (Negotiators of the European Union and the United Kingdom Government, 2017). The European Council then decided that discussions should move to a second phase in which a Withdrawal Agreement, including a transition period, would be negotiated.

These new negotiations resulted - on 19 March 2018 - in a Draft Agreement on the UK's withdrawal from the EU, including proposed arrangements for a transition period. This so-called 'coloured version' had agreed text highlighted in green, with yellow signifying that the text had not been finalised. Much of the text, however, was not highlighted indicating discussions were 'ongoing as no agreement [had] yet been found' (European Commission, 2018).

When the EU27 European Council reviewed this Draft Agreement it decided to press on with negotiations in the expectation that a Withdrawal Agreement could be concluded by autumn 2018. It was, however, made clear that the EU27 would want to be assured that a satisfactory resolution of the Irish border issue had been reached when the European Council next met in June 2018. They did nonetheless agree to open negotiations on the future UK-EU27 trading relations that would apply once the transition period had been concluded (an 'overall understanding of the framework for the future relationship'), whilst reiterating the position that 'nothing is agreed until everything is agreed' (European Council (2018, paragraphs $5 \& 1$ ). 
So, after all this endeavour, what can we now say with certainty about the postBrexit farm, food and rural policies that will apply in the UK; and what still needs to be decided? As the months have progressed, new issues and questions have emerged: thus it seems quite conceivable that other 'unknown unknowns' will materialise as Brexit proceeds.

\section{When, and what, does the UK leave?}

Article 50, which was triggered in March 2017, set in motion a two-year negotiation, after which (unless extended by agreement of both parties) the UK will leave the EU. The British Government has been adamant that this will occur at $11 \mathrm{pm}$ on 29 March 2019, although this intent could yet be disrupted. The Government has also been clear that this would involve leaving the EU customs union and its single (or Internal) market. Under the former the EU determines a common external trade regime with the European Commission representing the EU in the World Trade Organization (WTO), whilst the single market is a system of regulatory provisions providing for the free movement of goods, persons, services and capital throughout the territory of the EU.

Following speculation that the UK might seek to remain in the customs union, or negotiate a new customs union with EU27, 10 Downing Street issued a categorical denial, saying - it is reported - 'it is not our policy to stay in the customs union. It is not our policy to stay in a customs union'. ${ }^{1}$ There are, nonetheless, siren voices in British politics that favour a customs union, and significant regulatory harmony, between a post-Brexit UK and EU27.

In December 2017, reporting to the House of Commons on the negotiations that had led to the Joint Report, the Prime Minster said: 'when we leave the European Union, we will of course leave the common agricultural policy and the common fisheries policy' (May, 2017). As late as 11 March 2018 Michael Gove, the minister with overall responsibility for fisheries, had said: 'Britain will leave the CFP [common fisheries policy] as of March 2019'. ${ }^{2}$ We will contrast this later with the commitments the UK entered into in December 2017 in the Joint Report, and in the Draft Agreement of March 2018. 
To avoid a cliff-edge scenario on 29 March 2019 when the UK leaves the EU, with a sharp and sudden change in trade rules, both parties have agreed that there needs to be what the UK had referred to as an implementation period, but which the EU27's negotiators insisted would be a transition period, of about two-years duration. It is now agreed that the transition period will end on 31 December 2020, to coincide with the end of the EU's current multi-annual financial framework (MFF). As the Joint Report of December 2017 seemed to make clear to most observers, during this transition period EU law and policies (including the CAP, the CFP, and payments into and out of the EU budget) would continue to apply in the UK, and the UK's trade regime vis-à-vis third countries would exactly match that of the EU. As the green-shaded Article 122 of the Draft Agreement flatly declares, subject to some qualifications 'Union law shall be applicable to and in the United Kingdom during the transition period' (European Commission, 2018). Thus, the UK will remain a de facto member of the EU customs union and single market until the end of 2020. During this time, whilst the UK will not have a decision-making role, there are circumstances in which representatives of the UK will be invited to participate in meetings for selected agenda items, but without voting rights.

There are, though, a couple of concessions for the UK during the transition. First, with regard to trade agreements, 'the United Kingdom may negotiate, sign and ratify international agreements entered into in its own capacity in the areas of exclusive competence of the Union, provided those agreements do not enter into force or apply during the transition period, unless so authorised by the Union' (Article 124(4)). However there is a sequencing issue here: can the UK successfully negotiate, let alone conclude, new trade agreements before its new partnership with EU27 becomes clear?

The second concession relates to fisheries. The UK will be consulted when (probably in December 2019) the EU makes its annual decision on the allocation of fishing quotas, and 'the Union may exceptionally invite the United Kingdom to attend, as part of the Union delegation, international consultations and negotiations ...' (Article 125). 
It should also be noted that Regulation 1307/2013 establishing the direct payments regime will not apply in the UK for the 2020 claim year (Article 130), presumably because claims would ordinarily have been paid in the budget year 2021, when the provisions of the transition agreement will have lapsed. There is no mention, however, of Regulation 1306/2013, which sets out the rules on cross compliance.

What is not entirely clear about the transition is how this will affect EU27 and UK commitments under the WTO. Article 124 of the Draft Agreement states rather blandly that the 'United Kingdom shall be bound by the obligations stemming from the international agreements concluded by the Union ...', with a footnote adding: 'The Union will notify the other parties to these agreements that during the transition period, the United Kingdom is to be treated as a Member State for the purposes of these agreements'. If this represents a continuation in international law of the existing customs union, recognised by the WTO's membership, then trade between EU27 and the UK, and between the UK and the EU's Free Trade Area (FTA) partners, such as Canada, could continue as before. But if there is no formal EU27-UK customs union in place, recognised by the WTO's membership, how can EU27 offer the UK duty-free access, and vice versa, whilst not offering the same access to other WTO Members, in apparent breach of the WTO's fundamental most-favoured-nation (MFN) principle? Similarly, as Matthews (2018) has asked, whilst bound by the Withdrawal Agreement to apply EU27's tariff concessions on imports from the EU27's FTA partners, on what basis could the UK expect to enjoy the reciprocal tariff concessions the EU has negotiated in those overseas markets?

There is no guarantee that the Withdrawal Agreement will be successfully negotiated, or that it will ratified by the European and UK parliaments. Thus there is still the possibility of an abrupt Brexit in March 2019.

\section{What sort of future trade deal can be negotiated with the EU?}

The EU27 European Council has confirmed its readiness to initiate work towards a balanced, ambitious and wide-ranging free trade agreement (FTA) 
insofar as there are sufficient guarantees for a level playing field ... [which] will be finalised and concluded once the UK is no longer a Member State.' However, it opined, 'Being outside the Customs Union and the Single Market will inevitably lead to frictions in trade. This unfortunately will have negative economic consequences, in particular in the United Kingdom' (European Council 2018, paragraphs $8 \& 4)$.

Theresa May (2018) has said: 'When it comes to goods, a fundamental principle in our negotiating strategy should be that trade at the UK-EU border should be as frictionless as possible. That means we don't want to see the introduction of any tariffs or quotas. And ... we must ensure that, as now, products only need to undergo one series of approvals, in one country, to show that they meet the required regulatory standards.' In the same speech she also repeated the UK's determination to avoid recreating 'a hard border between Northern Ireland and Ireland', or to breaking up 'the United Kingdom's own common market by creating a customs and regulatory border down the Irish Sea'. In rejecting continued membership of a customs union, she correctly remarked that this 'would not be compatible with a meaningful independent trade policy', which is one of the UK Government's ambitions: 'A Global Britain which ... reaches out beyond our continent, to trade with nations across the globe.'

How these rather conflicting objectives can be reconciled is as yet unclear. Regulatory provisions, relating to food safety and animal and plant health for example, together with the high tariffs on many agri-food products, put the agriculture and food sectors at the core of the debate (Swinbank, 2018). Many commentators have suggested that the border between Northern Ireland and Ireland is particularly problematic. Addressing this concern in her Mansion house speech, Mrs May (2018) made two suggestions. Neither attracted the support of either the Irish Government or of the EU27 negotiator. One - later referred to as a 'maximum facilitation' arrangement - would use as-yet unproven technology to create as frictionless a border as possible. The second, later rubbished by Brexiteers in the House of Commons, was for a 'customs partnership'. As Theresa May (2018) explained: 
'At the border, the UK would mirror the EU's requirements for imports from the rest of the world, applying the same tariffs and the same rules of origin as the EU for those goods arriving in the UK and intended for the EU. By following this approach, we would know that all goods entering the EU via the UK pay the right EU duties, removing the need for customs processes at the UK-EU border.'

It is very difficult to envisage how this might work without a massive increase in bureaucracy. Presumably it would involve very close co-operation between customs officials in EU27 and the UK to ensure that the appropriate import taxes were collected, and correctly apportioned between the EU27 and UK treasuries. Furthermore, firms that took advantage of this facility would have to be subject to audit by both EU27 and UK customs officials right through the supply chain to ensure that products (at least on a mass balance basis) ended up in the intended market.

From the British perspective, one of the most politically charged aspects of the Joint Report was the EU27's view of how a hard border on the island of Ireland could be avoided from 1 January 2021, once the transition period is over, if arrangements for frictionless trade could not be negotiated to the EU27's liking. Three months later the Draft Agreement still contained a Protocol on Ireland/Northern Ireland. Most of this was un-shaded: i.e. not agreed. Article 4 read: 'The territory of Northern Ireland ... shall be considered to be part of the customs territory of the [European] Union', and 'Customs duties on imports and exports ... shall be prohibited between the Union and the United Kingdom in respect of Northern Ireland' (European Commission, 2018). Article 5 - again unagreed - on 'Agriculture and Fisheries' insists that much European Union law on sanitary and phytosanitary matters, and 'on the production and marketing of agricultural and fisheries products', would continue to apply in Northern Ireland. This contrasts sharply with Theresa May's (2018) rejection of 'a customs and regulatory border down the Irish Sea.' As Tangermann has commented elsewhere in this issue, the 'Irish border issue ... is closely related to the nature of arrangements that will govern trade between the UK and the EU after Brexit'; 
and it is difficult to see how the first can be settled without knowing the outcome on the second.

\section{Farm and rural policy in the UK?}

Agriculture is a devolved responsibility in the UK, but how much scope, or funding, there will be for the devolved administrations in Belfast, Cardiff and Edinburgh to pursue their own distinctive policies is as yet undetermined (Keating, 2018). It is the United Kingdom, for example, that has WTO membership and must ensure that all its constituent parts comply with its WTO undertakings. As we have seen above, the Prime Minister has emphasised the importance of unrestricted trade within the UK's own internal market, and in a recent consultation paper the Department for Environment, Food and Rural Affairs (Defra, 2018: 59) reported that the 'devolved administrations and the UK government are working together to determine where common frameworks need to be established'.

For England the intended direction of travel, outlined in Defra (2018) and further elaborated by Curnow in this volume, is clear. Thus direct payments would be phased out over an 'agricultural transition' period. Defra is consulting on how this might be pursued. One idea canvassed would be to 'continue to make payments to current recipients during the 'agricultural transition' period irrespective of the area farmed' (p. 22): an idea that echoes agricultural economists' writings in the 1960s, and more recently re-articulated in the Premier Edition of this journal (Swinbank and Tangermann, 2001) and recommended in relation to Brexit by Tangermann (2016).

Another clear message from the consultation paper is that there should be a 'new agricultural policy ... underpinned by payment of public money for the provision of public goods' (Defra, 2018: 32). Thus: 'After [the] 'agricultural transition', we propose that Direct Payments will end in England and be replaced with a system of public money for public goods, principally environmental enhancement' ( $p$. 20). Although the document repeatedly uses the phrase 'public goods', and 
suggests what they might be, how the slogan can be operationalized and fashioned into effective policies across widely varying landscapes and environmental conditions has yet to become clear. Can increased funds be costeffectively spent on these public goods in a way that will ensure long-term political support from British taxpayers (and government), and how does this commitment relate to 'a strong regulatory baseline of standards that reflects the 'polluter pays' principle' ... setting out minimum standards that all farmers and land managers must comply with' (p. 50)?

\section{Food prices, availability, safety}

There has been considerable speculation about the likely impact of Brexit on food prices, availability, and safety in the UK. A headline in The Independent in February 2018, for example, reporting on a committee hearing in the House of Lords, read: 'Brexit Britain at risk from food shortages, rising prices and lower animal welfare standards'. ${ }^{3}$

Over and above any movements in world commodity prices, four directly-related Brexit impacts on food prices can be identified: i) the exchange rate; ii) any change in trade facilitation costs, particularly on the UK's imports from EU27; iii) the trade regime the UK chooses to pursue after Brexit, and iv) any supply difficulties UK producers might face - as a result, for example, of reduced access to migrant labour.

Trade facilitation costs might increase because of checks to ensure regulatory compliance, monitor rules of origin, undertake Value Added Tax (VAT) formalities and the payment of import tariffs, and apply cabotage rules regarding movement of lorries and drivers, even if all these administrative activities can be undertaken electronically at a 'virtual', rather than a physical, border. Adams and Capparelli (2018) have outlined the complications the food and drink industries could face grappling with rules of origin in an UK-EU27 FTA.

The international value of the pound did suffer a steep decline on 23 June 2016, following the referendum, and again in October 2016, as illustrated in Figure 1. However the extent to which its subsequent trajectory has been influenced by Brexit rather than the actions of the Bank of England, or developments in the 
international economy (compare the divergent movements against the US dollar and the Euro), is a more open question, as is sterling's likely future value. Some saw the referendum-induced fall in sterling as evidence of the costs of Brexit, feeding through to higher business costs and retail prices (including food). Others welcomed Brexit's first dividend, as a lower value of sterling was expected to improve the competitiveness of British exports and tourism. One impact that Britain's farmers did notice was that the sterling value of payments under the Basic Payment Scheme for 2016 were 16.5 per cent higher than they had been a year earlier. ${ }^{4}$

Supply constraints because of border congestion and delays, particularly for fresh produce, could result in price increases in British shops, and some lines temporarily disappearing from shelves, especially in the immediate aftermath of the UK's departure from the customs union and single market (be that 29 March 2019, 1 January 2021, or whenever) if new computer systems and physical infrastructures are not fully operational. The UK could simply open its borders as some Brexiteers have suggested - although it would then have to ensure that the arrangements put in place did not infringe its WTO commitments. The outcome, though, is likely to be asymmetric. In the absence of a detailed FTA covering regulatory measures and customs procedures, there would be no obligation on EU27 to relax its border controls and invest in appropriate infrastructure, and consequently UK exports could still face considerable border delays in Ireland, Calais, Rotterdam, etc. 
Figure 1: Indices of the value of Sterling in US dollars and euros (22 June

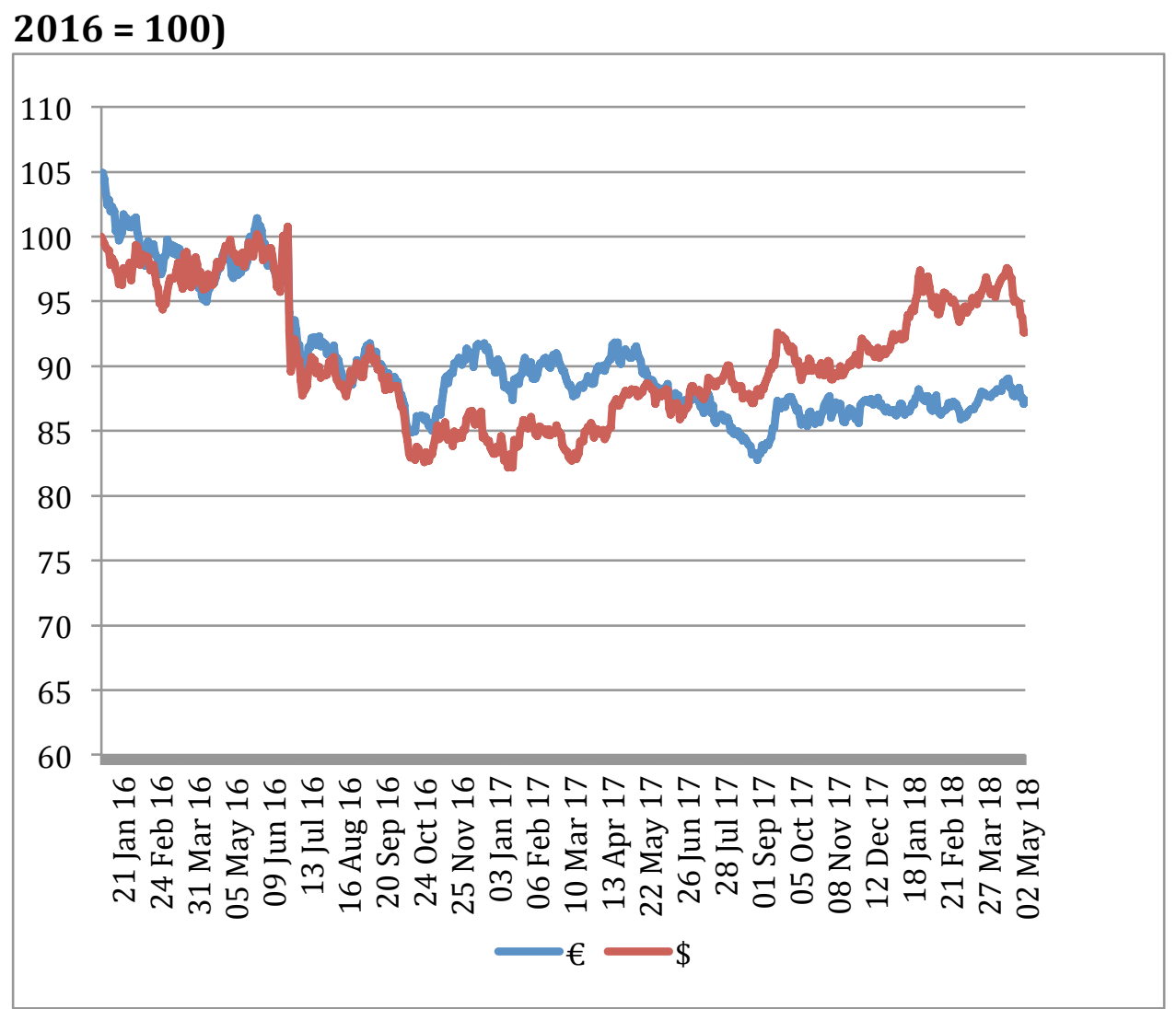

22 June 2016, $€ 1=1.3018$ Euro $(€) / 1.4687$ US\$

2 May 2018, $€ 1=1.1374$ Euro (€)/1.3599 US\$

As a WTO Member the UK would be able to apply sanitary and phytosanitary measures that comply with WTO norms, although imposing animal welfare standards on imported products could be more problematic. But some analysts fear that, in seeking to secure new FTAs with countries such as Brazil, the USA, etc., the UK might be pressured to accept lower animal welfare and food safety standards, with the use of chlorine washing of poultry as a pathogen control frequently cited as a particularly egregious example.

Indeed, if the UK simply continues to apply the existing body of EU legislation it might prove more vulnerable than is EU27 to challenge under the WTO's Dispute Settlement procedure, for example from President Donald Trump's USA. His Special Trade Representative has a long list of contested issues with the EU. As well as genetically modified organisms and the on-going beef hormones dispute, 
this list includes a complaint that 'The EU requires that for a product to be labeled 'whiskey' (or 'whisky'), it must be aged a minimum of three years'; and that proposals for a new Renewable Energy Directive would 'introduce onerous and complex sustainability criteria for biomass and could be extremely problematic for U.S. exports of sustainable wood pellets' (Lighthizer, 2018: 165 $\& 161)$.

\section{Modelling Brexit's impact on the agri-food sector}

This article does not attempt to review the growing literature that attempts to model the impact of various Brexit scenarios on the agri-food sector. Two studies have been reported in this volume (Hubbard et al., and van Berkum et al.) and papers by Jongeneel et al. (2016) and Feng et al. (2017) were published in earlier issues of EuroChoices. Mention might also be made of Bellora et al.'s (2017) work reported to the European Parliament, and Bradley and Hill's (2017) study for the Agricultural and Horticultural Development Board.

Four components have typically been identified in the modelling studies to date: i) changes to the tariff regime and trade facilitation costs, ii) reductions and/or modifications in taxpayer support for farming and the rural environment, iii) EU migration and access to labour, and iv) a change in the regulatory regime. A number of policy choices have yet to be made which will impact on the future fortunes of the farm and food industries, consumers, and the rural environment, and models will continue to differ in how they do or do not treat these variables and their possible linkages.

What the overall impact of Brexit on the economy will be is still debated. Tangermann, in this issue, suggests it will be 'significant'. A number of free market advocates, however, still insist that greater economic prosperity can be gained by breaking completely from the EU, its tariffs, and its policies. Patrick Minford for example, based on results from his World Trade Model, believes that to achieve this 'It is absolutely essential, whatever other decisions are taken, that the UK government withdraws totally and unconditionally from the CAP and all its associated tariffs on agricultural products' (Economists for Free Trade, 2017). 


\section{Much uncertainty remains}

Despite the title of this paper, and the confidence Theresa May's administration has expressed, much in fact remains to be legally determined. Many aspects of the Brexit process are still hotly contested. Furthermore, the article's coverage of issues has been less than complete. We know, for example, that the UK must establish its own Schedule of Commitments when it resumes its place in the WTO, but when and how this is to be done remains unsettled. As this article goes to press the withdrawal negotiations are continuing. As and when you read this, you might have a clearer picture of how the negotiations have progressed.

\section{Summary}

Brexit negotiations were triggered in March 2017 when the UK notified its intention to leave the EU. A year later, a draft Withdrawal Agreement was produced. It is hoped that this will result in a legally binding agreement when the European Council meets in autumn 2018, but this is not guaranteed. The draft provides for a transitional period, extending from March 2019 - when the UK will formally leave the EU - to the end of 2020, during which time EU law and policies - including the common agricultural policy - will continue to apply. The UK-EU27 trade arrangements that will apply from 1 January 2021 are yet to be determined. Both the UK and EU27 insist they are determined to keep open the Irish border, but how this outcome can be reconciled with the UK's stated ambition of forging new trade links around the world, is yet to be determined. Regulatory provisions, relating to food safety and animal and plant health for example, together with the high tariffs on many agri-food products, put the agriculture and food sectors at the core of this debate. Direct payments will be phased out in England, but the scope for policy divergence between the various nations of the UK is uncertain.

\section{Pullquote}

"There is no guarantee that the Withdrawal Agreement will be successfully negotiated...thus there is still the possibility of an abrupt Brexit in March 2019" 


\section{Further Reading}

Adams, Stephen \& Daniel Capparelli (2018), Rules of origin in an EU-UK FTA. A 'hidden hard Brexit' for food and drink exporters? (Global Counsel for the Food and Drink Federation and National Association of British and Irish Millers: London).

Bellora, Cecilia, Charlotte Emlinger, Jean Fouré \& Houssein Guimbard (2017), EU-UK agricultural trade: state of play and possible impacts of Brexit, PE 602.008 (European Parliament: Brussels).

Bradley, Dylan \& Berkeley Hill (2017), Quantitative Modelling for Post-Brexit Scenarios, Final report for AHDB (Agribusiness Consulting/Informa: London).

Defra (2018), Health and Harmony: the future for food, farming and the environment in a Green Brexit, Cm 9577 (HMSO: London).

Economists for Free trade (2017), Submission 57 to the Australian Parliament's Joint Standing Committee on Foreign Affairs, Defence and Trade:

http://www.aph.gov.au/Parliamentary_Business/Committees/Joint/Foreign_Aff airs_Defence_and_Trade/tradewithUK/Submissions

European Commission (2018), Draft Agreement on the withdrawal of the United Kingdom of Great Britain and Northern Ireland from the European Union and the European Atomic Energy Community highlighting the progress made (coloured version) in the negotiation round with the UK of 16-19 March 2018, 19 March: https://ec.europa.eu/commission/sites/betapolitical/files/draft_agreement_coloured.pdf

European Council (2018), European Council (Art. 50) (23 March 2018) Guidelines, EUCO XT 20001/18:

http://www.consilium.europa.eu/media/33458/23-euco-art50-guidelines.pdf

Feng, Siyi, Myles Patton, Julian Binfield \& John Davis (2017), 'Deal' or 'No Deal'? Impacts of Alternative Post-Brexit Trade Agreements on UK Agriculture, EuroChoices, 16(3): 27-33.

Jongeneel, Roel, Siemen van Berkum \& Hans Vrolijk (2016), Brexit: Breaking Away - Would it Pay?, EuroChoices 15(2): 26-33.

Keating, Michael (2018), The Repatriation of Competences in Agriculture after Brexit (Centre on Constitutional Change: Edinburgh).

Lighthizer, Robert E. (2018), 2018 National Trade Estimate Report on Foreign Trade Barriers (Office of the United States Trade Representative: Washington D.C.).

Matthews, Alan (2018), Brexit Withdrawal Agreement forwarded to UK, http://capreform.eu/brexit-withdrawal-agreement-forwarded-to-uk/

May, Theresa (2017), Hansard online, 11 December, Column 46: https://hansard.parliament.uk/Commons/2017-12-11/debates/965E301041F6-4353-A2CC-2F5A6C31495F/BrexitNegotiations (accessed 5 April 2018).

May, Theresa (2018), Prime Minister Theresa May's speech on our future economic partnership with the European Union, Mansion House 2 March: 
https://www.gov.uk/government/speeches/pm-speech-on-our-futureeconomic-partnership-with-the-european-union

Negotiators of the European Union and the United Kingdom Government (2017), Joint Report from the Negotiators of the European Union and the United Kingdom Government on Progress During Phase 1 of Negotiations Under Article 50 TEU on the United Kingdom's Orderly Withdrawal from the European Union, 8 December 2017: https://ec.europa.eu/commission/publications/joint-report-negotiatorseuropean-union-and-united-kingdom-government-progress-during-phase-1negotiations-under-article-50-teu-united-kingdoms-orderly-withdrawaleuropean-union_en (accessed 27 February 2018).

Swinbank, Alan (2018), 'Brexit, Ireland and the World Trade Organization: possible policy options for a future UK-Australia agri-food trade agreement', Australian Journal of International Affairs, https://www.tandfonline.com/eprint/XY6T45HT2Icv8e9yJIKn/full .

Swinbank, Alan \& Stefan Tangermann (2001), 'The Future of Direct Payments under the CAP: A Proposal', EuroChoices, Premier Issue: 28-29.

Tangermann, Stefan (2016), 'Analysis: What future for direct payments in the UK after Brexit?', Agra Europe 11 November:

https://iegpolicy.agribusinessintelligence.informa.com/PL040372/Analysis-

What-future-for-direct-payments-in-the-UK-after-Brexit

Endnotes:

1 https://www.independent.co.uk/news/uk/politics/brexit-latest-downingstreet-uk-categorically-leaving-customs-union-theresa-may-jacob-rees-mogga8194391.html (accessed 5 April 2018).

2 'Ruth Davidson and Michael Gove back a fair deal on fishing', 11 March 2018:

http://www.scottishconservatives.com/2018/03/ruth-davidson-and-michael-gove-back-a-fairdeal-on-fishing/ (accessed 24 March 2018).

${ }^{3}$ https://www.independent.co.uk/news/business/news/brexit-uk-risk-foodshortage-rising-prices-animal-welfare-lords-committee-a8199326.html (accessed 19 March 2018).

${ }^{4}$ https://www.gov.uk/government/news/euro-exchange-rate-set-for-2016basic-payment-scheme-payments (accessed 19 March 2018). 